\title{
ANALISIS KELAYAKAN INDUSTRI TAHU DI DESA KANCINAA KECAMATAN PASARWAJO KABUPATEN BUTON (Studi Kasus pada IKM DWI BERKAH)
}

\author{
Safrin Edy ${ }^{1}$, Trisnawati Imran ${ }^{2}$ \\ Program Studi Agribisnis, Fakultas Pertanian \\ Universitas Muhammadiyah Buton \\ Jl. Betoambari No. 36 Baubau \\ safrinediumb@gmail.com
}

\begin{abstract}
The aim of this research was: (1) to find out the amount of income received from the tofu business; (2) to find out the value of the viability of the tofu business. This research was carried out in the IKM Dwi Berkah industry in Kancinaa Village, Pasarwajo Sub-district, Buton Regency from July to August 2019, considering that the Kancinaa Village was one of the areas of tofu business and that the area was easily reached. This type of research is a case study, so that tofu-making business owners are used as a source to gather the information needed by researchers. The data obtained were then analyzed using a profit analysis of $\pi=$ $T R-T C$ and researchers used the $R / C$ ratio formula to determine the feasibility of the business. The results of this research show that the profit is 58,094,450 IDR/month in a single production process. In addition, the $1.51 \mathrm{R} / \mathrm{C}$ ratio was also achieved in such a way that the IKM Dwi Berkah tofu industry was competitive and viable to grow in the Kancinaa Village Pasarwajo Sub-district of Buton Regency.
\end{abstract}

Keywords: feasibility, efficiency, cost, tofu industry

\section{ABSTRAK}

Tujuan dari penelitian ini adalah untuk: (1) mengetahui besarnya pendapatan yang di terima dari usaha pembuatan tahu (2) mengetahui besarnya nilai kelayakan usaha usaha pembuatan tahu. Penelitian ini dilaksanakan di Industri IKM Dwi Berkah di Desa Kancinaa Kecamatan Pasarwajo Kabupaten Buton pada bulan Juli sampai Agustus 2019 dengan pertimbangan Desa Kancinaa tersebut merupakan salah satu daerah yang melakukan usaha tahu dan daerah tersebut mudah di jangkau. Penelitian ini adalah Studi Kasus sehingga pemilik usaha pembuatan tahu dijadikan sebagai sumber untuk memperoleh informasi sesuai yang dibutuhkan oleh peneliti. Data yang diperoleh kemudian dianalisis menggunakan analisis keuntunga $\pi=T R-T C$ dan untuk mengetahui kelayakan usaha menggunakan rumus $R / C$ Rasio. Hasil penelitian ini menunjukkan bahwa keuntungan yang dalam satu kali proses produksi sebesar Rp 58.094.450/bulan. Nilai R/C rasio sebesar 1,51 dengan demikian bahwa industri tahu IKM Dwi Berkah di Desa Kancinaa Kecamatan Pasarwajo Kabupaten Buton menguntungkan dan layak dikembangkan.

Kata Kunci: Kelayakan, Efisiensi, biaya, Industri Tahu 


\section{PENDAHULUAN}

\section{Latar Belakang}

Sektor pertanian dan industri merupakan sektor yang saling terkait satu sama lain. Pertanian sebagai penyedia bahan baku, sedangkan industri mengolah hasil pertanian untuk memperoleh nilai tambah. Industri kecil mempunyai peranan yang sangat besar terhadap roda perekonomian suatu negara. Industri kecil yang mengolah hasil-hasil pertanian (agroindustri) tahan terhadap dampak krisis ekonomi bersifat padat karya merupakan salah satu alternatif dalam membangun kembali perekonomian Indonesia saat ini. Industri kecil dapat menciptakan lapangan kerja bagi masyarakat sekitar perusahaan, juga dapat menciptakan nilai tambah bagi produk pertanian khususnya pangan (Assauri,2004).

Pengembangan industri kecil adalah cara yang dinilai besar peranannya dalam pengembangan industri manufaktur. Pengembangan industri kecil akan membantu mengatasi masalah pengangguran mengingat teknologi yang digunakan adalah teknologi padat karya sehingga bisa memperbesar lapangan kerja dan kesempatan usaha, yang pada gilirannya mendorong pembangunan daerah dan kawasan pedesaan (Kuncoro, 2007). Industri kecil yang mengolah hasil-hasil pertanian dan mampu bertahan terhadap dampak krisis ekonomi merupakan salah satu alternatif dalam membangun kembali perkonomian Indonesia saat ini. Selain dapat menciptakan lapangan pekerjaan bagi masyarakat sekitar perusahaan, industri kecil juga dapat menciptakan nilai tambah bagi produk pertanian. Salah satu industri kecil yang potensial untuk dikembangkan adalah pabrik pembuatan tahu. Konsumen tahu sangat luas dan mencakup semua strata sosial. Tahu tidak hanya di konsumsi oleh masyarakat kelas bawah, dan menengah saja, akan tetapi juga kelas atas. Hal ini dapat di lihat telah masuknya banyak produk tahu di pasar tradisional sampai retail modern.

Komoditas pertanian yang ada selama ini hampir semuanya bisa diolah seperti kacang kedelai. Kedelai merupakan bahan pangan yang sangat populer di dalam kalangan masyarakat hampir setiap hari banyak orang yang mengonsumsi makanan olahan dari kedelai salah satunya tahu. Kandungan protein yang tinggi pada kedelai dan juga kandungan gizinya yang lengkap, di mana kacang kedelai merupakan bahan baku utama pembuatan tahu yang sangat dibutuhkan bagi berlangsungnya suatu proses produksi. Bila dilihat dari nilai ekonomisnya, kebutuhan akan tahu sangat tinggi setiap harinya. Karena tahu merupakan makanan yang enak bagi semua kalangan, banyak manfaat yang bisa di peroleh dari tahu baik dari segi kesehatan maupun ekonomis. Usaha pembuatan tahu dirasa memberikan kontribusi pendapatan yang baik bagi produsen karena permintaan tahu tidak pernah turun, sehingga meningkatkan taraf hidup pengusaha serta banyak dari produsen ingin mengembangkan usaha untuk kedepannya melalui pemasaran yang optimal (Cahyadi, 2007).

Kedelai merupakan tanaman subtropik yang multiguna sudah sejak dulu di manfaatkan sebagai salah satu sumber pemenuhan protein nabati di berbagai negara, terutama Indonesia. Kedelai merupakan tanaman jenis kacang-kacangan yang biasa diolah masyarakat menjadi bentuk pangan olahan. (Warisno dan Kris, 2010). Kedelai (Glycine max L) merupakan komoditas pangan yang telah lama dibudidayakan di Indonesia, yang saat ini tidak hanya diposisikan sebagai bahan baku industri pangan, namun juga ditempatkan sebagai bahan baku, khususnya pembuatan tahu. Ironisnya sampai saat ini Indonesia masih mengimpor kedelai dari negara lain untuk memenuhi kebutuhan dalam negeri. Kalangan industri tahu (pengrajin) cenderung memiliki kedelai impor sebagai bahan baku dibanding kedelai nasional karena pasokan bahan bakunya terjamin (Setiadi, 2008). 
Industri kecil yang potensial untuk dikembangkan, salah satunya adalah usaha pembuatan tahu. Tahu merupakan makanan tradisional sebagian besar masyarakat Indonesia, dan digemari hampir seluruh lapisan masyarakat. pembuatan tahu relatif murah dan sederhana, namun dalam upaya pengembangan industri tahu yang ramah lingkungan sangat diperlukan sebagai upaya meminimalisasi dampak negatif terhadap lingkungan. Berdasarkan data Badan Pusat Statistik, sekitar 38\% kedelai di Indonesia dikonsumsi dalam bentuk produk tahu (BPS, 2017). Seiring dengan bertambahnya jumlah penduduk Indonesia dari tahun ke tahun, maka permintaan dalam negeri terhadap produk pangan yang merupakan hasil olahan dari biji kedelai khususnya tahu mengalami pertumbuhan (Sarwono, 2005).

Provinsi Sulawesi Tenggara merupakan salah satu daerah yang cocok untuk dikembangkan tanaman kacang kedelai. Beberapa daerah di Sulawesi Tenggara sudah mengolah tanaman kacang kedelai salah satunya adalah Kabupaten Buton, akan tetapi hanya bertujuan untuk penjualan kacang kedelai dan konsumsi. Pengusaha di Kabupaten Buton mulai melihat peluang ini dan mengembangkan agroindustri dengan mengolah biji kedelai menjadi tahu. Salah satunya adalah Indutri Tahu IKM Dwi Berkah yang ada di Desa Kancinaa Kecamatan Pasarwajo Kabupaten Buton. Produksi tahu di daerah pada umumnya masih dilakukan secara tradisional dan pengelolaan system keuangannya belum tertata dengan baik, sehingga pengrajin belum mengetahui sacara rinci berapa besar pendapatan yang diperoleh dalam produksi dan nilai kelayakan dari usaha tahu tersebut. Berdasarkan uraianuraian tersebut, penualalis tertarik untuk meneliti menganalisis apakah usaha tahu tersebut layak diusahakan secara ekonomi.

Berdasarkan latar belakang yang telah diuraikan di atas maka rumusan masalah pada penelitian ini adalah:

1. Berapa besar pendapatan yang di terima dari usaha pembuatan tahu pada Indutri Tahu IKM Dwi Berkah yang ada di Desa Kancinaa Kecamatan Pasarwajo Kabupaten Buton?

2. Berapa besar nilai kelayakan usaha pembuatan tahu pada Indutri Tahu IKM Dwi Berkah yang ada di Desa Kancinaa Kecamatan Pasarwajo Kabupaten Buton?.

Tujuan yang ingin dicapai dalam penelitian ini adalah untuk:

1. Mengetahui besarnya pendapatan yang di terima dari usaha pembuatan tahu pada Indutri Tahu IKM Dwi Berkah yang ada di Desa Kancinaa Kecamatan Pasarwajo Kabupaten Buton.

2. Mengetahui besarnya nilai kelayakan usaha usaha pembuatan tahu pada Indutri Tahu IKM Dwi Berkah yang ada di Desa Kancinaa Kecamatan Pasarwajo Kabupaten Buton.

\section{METODE PENELITIAN}

Penelitian ini dilakukan di Desa Kancinaa Kecamatan Pasarwajo Kabupaten Buton yang di laksanakan pada Bulan Juli sampai agustus 2019 dengan pertimbangan Desa Kancinaa tersebut merupakan salah satu daerah yang melakukan usaha tahu dan daerah tersebut mudah di jangkau. Penelitian ini adalah studi kasus, yaitu penelitian yang bertujuan memberikan gambaran secara mendetail tentang latar belakang, sifat maupun karakter yang khas dari suatu kasus, meliputi tahapan kegiatan pelaksanaan pekerjaan persiapan, pengumpulan data, pengolahan dan analisis data serta pembahasan. Subjek penelitian ini yaitu 


\section{P-ISSN: 2527-8479 E-ISSN: 2686-2174}

pimpinan industri dan 4 orang karyawan Industri Tahu di IKM Dwi Berkah. Pertimbangannya adalah pimpinan berperan sebagai bagian administrasi dan keuangan serta empat orang karyawan yang aktif dalam kegiatan produksi dan pemasaran, yang akan memberikan data dan informasi yang dibutuhkan oleh peneliti.

Data yang digunakan dalam penelitian ini adalah data primer dan data sekunder. Data primer diperoleh dari pengusaha industri tahu responden melalui teknik wawancara dengan menggunakan kuesioner yang telah dipersiapkan. Data sekunder diperoleh dari berbagai sumber,seperti literature atau buku-buku perpustakan, arsip/data-data yang ada pada obyek penelitian ( Kantor Desa Kancinaa , Kantor Kecamatan Pasarwajo dan Biro Pusat Statistik) dan instansi lain yang terkait, serta internet.

Variabel yang diamati dalam penelitian ini adalah:

1. Identitas responden yang meliputi umur, tingkat pendidikan, jumlah tanggungan keluarga, pengalaman usaha industry tahu .

2. Karakteristik industri yang meliputi: produksi, harga, biaya produksi, penerimaan, dan keuntungan.

Metode analisis data yang digunakan dalam penelitian ini yakni secara kuantitatif, meliputi tahap tarnser data, editing data, pengolahan data dan interpretasi data secara deskriptif.

Metode analisis yang digunakan dalam penelitian ini adalah analisis pendapatan dan analisis permintaan. Analisis pendapatan secara matematis persamaannya dituliskan dengan menggunakan rumus sebagai berikut:

$$
I=T R-T C
$$

Keterangan:

$\mathrm{I}=$ Pendapatan

$\mathrm{TR}=$ Total Revenue (Total Penerimaan)

$\mathrm{TC}=$ Total cost $($ Total Biaya $)$

Total biaya dapat di hitung dengan menggunakan rumus sebagai berikut:

$$
\mathrm{TC}=\mathrm{FC}+\mathrm{VC}
$$

Keterangan :

$\mathrm{TC}=$ Total Biaya $(\mathrm{Rp} / \mathrm{bln})$

$\mathrm{FC}=$ BiayaTetap $(\mathrm{Rp} / \mathrm{bln})$

$\mathrm{VC}=$ BiayaVariabel $(\mathrm{Rp} / \mathrm{bln})$

Suratiyah (2015), menyatakan bahwa penerimaan adalah perkalian antara jumlah produksi yang dihasilkan dengan harga jual produk. Secara matematis jumlah penerimaan dapat dituliskan sebagai berikut:

$$
T R=Y x P y
$$

Keerangan:

$T R=$ Penerimaan total $(\mathrm{Rp} / \mathrm{bln})$ 
$Y=$ Jumlah produksi

$P y=$ Harga dari hasil produksi (Rp/bln)

Untuk mengetahui apakah Industri Tahu IKM Dwi Berkah dalam melakukan proses produksi mengalami keuntungkan, impas dan rugi digunakan analisis $R / C$ rasio yaitu perbandingan (nisbah) antara jumlah penerimaan dengan jumlah pengeluaran selama proses produksi (Kartasapoetra, 1988).

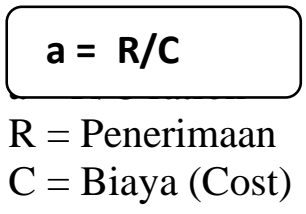

Dengan kriteria:

R/C- Ratio> 1 : Usaha menguntungkan secara ekonomi dan penggunaan biaya produksi efisien.

$\mathrm{R} / \mathrm{C}-$ Ratio $=1:$ Usaha industri tahu mengalami impas.

R/C- Ratio $<1$ : Usaha industri tahu tidak menguntungkan.

\section{Definisi Operasional}

Konsep operasional adalah pengertian-pengertian atau batasan-batasan yang digunakan untuk menghindari kesalahan pemahaman dalam mendefinisikan beberapa variabel pengamatan. Beberapa konsep operasional dalam penelitian ini adalah sebagai berikut:

1. Responden adalah pimpinan industri dan 4 orang karyawan bagian produksi Industri Tahu di IKM Dwi Berkah Desa Kancinaa Kecamatan Pasarwajo Kabupaten Buton.

2. Produksi adalah banyaknya tahu yang dihasilkan oleh Industri selama satu bulan (bulan).

3. Biaya total adalah jumlah keseluruan biaya yang dikeluarkan dalam satu kali produksi (Rp/proses produksi).

4. Biaya tetap adalah sejumlah uang yang di keluarkan dalam usaha yang tetap jumlahnya tidak tergantung pada skala produksi di ukur pada satuan rupiah ( $\mathrm{Rp}$ ).

5. Biaya variabel adala sejumlah uang dikeluarkan dalam usaha produksi tahu yang besar kecilnya tergantung dari skala produksi dan di ukur dalam satuan rupiah (Rp).

6. Penerimaan adalah nilai produksi yang diperoleh dari perkalian antara produksi dengan harga (Rp/bulan).

7. Pendapatan adalah penerimaan yang diperoleh pengusaha dari penjualan tahu setelah dikurangi dengan biaya-biaya yang digunakan selama proses produksi dinyatakan dalam rupiah ( $\mathrm{Rp} / \mathrm{bulan})$

8. $R / C$ Rasio adalah perbandingan antara penerimaan total dan biaya yang dikeluarkan oleh produsen.

9. Kelayakan usaha adalah kegiatan untuk menilai sejauh mana manfaat yang dapat diperoleh dalam melaksanakan suatu kegiatan usaha.

\section{HASIL DAN PEMBAHASAN}

\section{Gambaran Umum Perusahaan}

Perusahaan pada lokasi penelitian di Industri tahu IKM Dwi Berkah di Desa Kancinaa Kecamatan Pasarwajo Kabupaten Buton adalah industry kecil atau industry rumah tangga yang bergerak di bidang produksi pangan khususnya memproduksi tahu. Industri ini belum 
mendapatkan izin dari badan POM (Pengawasan Obat dan Makanan), SIUP (Surat Izin Usaha Perindustrian), maupun SITU (Surat Izin Tempat Usaha) yang dikeluarkan oleh Departemen perindustrian dan Perdagangan karena industry tahu ini masih tergolong industry kecil rumah tangga. Lokasi industry ini berada di Desa Kancinaa Kecamatan Pasarwajo Kabupaten Buton yang didirikan oleh Ibu Suharni dibantu suaminya Bapak Toni. Industri ini telah berdiri selama 16 tahun sejak tahun 2003 dengan karyawan saat ini berjumlah 4 orang, 1 orang bagian pemasaran dan 3 orang di bidang produksi yang dibagi sesuai dengan bagiannya masing-masing. Industri ini awalnya dibangun untuk membantu dan mendorong pertumbuhan perekonomian sebagai salah satu sumber pendapatan dalam rangka meningkatkan taraf hidup keluarganya, dengan menggunakan modal sendiri sebesar Rp 2.000.000 dan pinjaman kepada desa (Bantesa) sebesar Rp 3.000.000.

Sejak berdirinya hingga saat ini industry tahu terus mengalami peningkatan produksinya meskipun sempat jatuh bangun pada awal mula pendiriannya. Namun lama kelamaan seiring makin banyaknya konsumen, industry tahu ini menjadi semakin besar dan memiliki banyak pelanggan diberbagai daerah dikabupaten Buton di antaranya Desa Kabawa Koleh, Desa Kaumbu, Desa Galanti, Desa Wolowa, Kelurahan Wasaga, Kelurahan Wakoko, Kelurahan Saragi serta mencapai perbatasan Kecamatan Wabula, dan Kecamatan Lasalimu Selatan.

Tabel 1 : Jumlah Produksi Tahu di IKM Dwi Berkah 5 tahun trakhir 2014-2018

\begin{tabular}{lrrrr}
\hline No. & Tahun & $\begin{array}{c}\text { Jumlah produksi } \\
\text { Kedelai }(\mathrm{Kg})\end{array}$ & $\begin{array}{c}\text { Jumlah } \\
\text { potongan tahu }\end{array}$ & \multicolumn{2}{c}{ Persentase \% } \\
\hline 1. & 2014 & 23763 & 371,29 & 17,85 \\
\hline 2. & 2015 & 25189 & 393,93 & 18,94 \\
\hline 3. & 2016 & 26700 & 417,18 & 20,07 \\
\hline 4. & 2017 & 28302 & 442,21 & 21,27 \\
\hline 5. & 2018 & 29105 & 454,76 & 21,88 \\
\hline & Jumlah & 133059 & $2,079,01$ & 100 \\
\hline
\end{tabular}

Sumber : IKM Dwi Berkah

Berdasarkan table 1 mengenai jumlah produksi tahu di industry IKM Dwi Berkah selama 5 tahun terakhir mengalami peningkatan produksi. Tahun 2014 jumlah permintaan berkisar $23.763 \mathrm{~kg}$ jumlah potongan tau 371,29 atau 17,85\%. Kemudian pada tahun 2015 meningkat menjadi $25.189 \mathrm{~kg}$ jumlah potongan tahu 393,57 atau 18,94\%, pada tahun 2016 jumlah produksi $26.700 \mathrm{~kg}$ jumlah potongan tahu 417,18 atau 20,07\%, pada tahun 2017 jumlah produksi mencapai $28.302 \mathrm{~kg}$ jumlah potongan tahu 442,21 atau meningkat menjadi $21,27 \%$ dan pada tahun 2018 jumlah produksi menjadi $29.105 \mathrm{~kg}$ jumlah potongan tahu 454,76 atau $21,87 \%$. Ini maksudnya bahwa dari tahun ke tahun jumlah produksi tahu di industry IKM Dwi Berkah mengalami peningkatan.

Tabel 2: Proyeksi Permintaan Tahu di IKM Dwi Berkah Tahun 2014-2018

\begin{tabular}{lccc}
\hline No & Tahun & Jumlah Permintaan $(\mathrm{kg})$ & Persentase $\%$ \\
\hline 1 & 2014 & 30.000 & 17,74 \\
\hline 2 & 2015 & 31.800 & 18,80 \\
\hline 3 & 2016 & 33.708 & 19,93 \\
\hline 4 & 2017 & 35.730 & 21.13 \\
\hline
\end{tabular}




\begin{tabular}{cccc}
\hline 5 & 2018 & 37.874 & 22,40 \\
\hline & Jumlah & 169112 & 100 \\
\hline
\end{tabular}

Tabel 2 menunjukan proyeksi permintaan tahu di Industri IKM Dwi Berkah di dapatkan hasil proyeksi permintaan bahwa usaha Tahu setiap tahunnya terus mengalami peningkatan. Dari tahun 2014 poyeksi permintaan mencapai 30.000kg atau 17,74\% hingga tahun 2018 meningkat menjadi $37.874 \mathrm{~kg}$ atau 22,40\%. Sehigga prospek pasar untuk tahu ini masih cukup bagus dan layak untuk dikembangkan.

Struktur organisasi merupakan salah satu faktor yang dapat menunjang kelancaran kegiatan produksi. Karena tanpa adanya struktur organisasi maka tugas dan tanggung jawab dari masing-masing tenaga kerja dan juga pimpinan tidak mungkin mampu sendiri melaksanakan seluruh kegiatan usaha, dia harus mempercayakan sebagian bebannya kepada orang lain. Dilain pihak organisasi juga merupakan sekelompok orang dengan seperangkat komponen-komponen yang berinteraksi guna mencapai tujuan, dalam hal ini yaitu untuk memperoleh keuntungan atau pendapatan maksimum agar tetap mampu mempertahankan kegiatan produksinya secara berkesinambungan. Suksesnya suatu usaha juga sangat di pengaruhi oleh struktur organisasi yang baik, karena pimpinan dapat melaksanakan fungsinya sebagai pimpinan yang baik, mengawasi secara keseluruhan dari suatu usaha dengan adanya pengorganisasian.

Struktur organisasi pada Industri IKM Dwi Berkah tidak ditetapkan dalam bentuk yang baku atau tertulis, akan tetapi berdasarkan informasi dari hasil penelitian yang dilakukan maka terlihat adanya pembagian/pengelompokan pekerjaan berdasarkan tugas dan tanggung jawab serta jenis pekerjaan yang ada. Adapun bentuk dari struktur Organisasi pada Industri Tahu IKM Dwi Berkah Desa Kancinaa dapat dilihat pada Gambar 1.

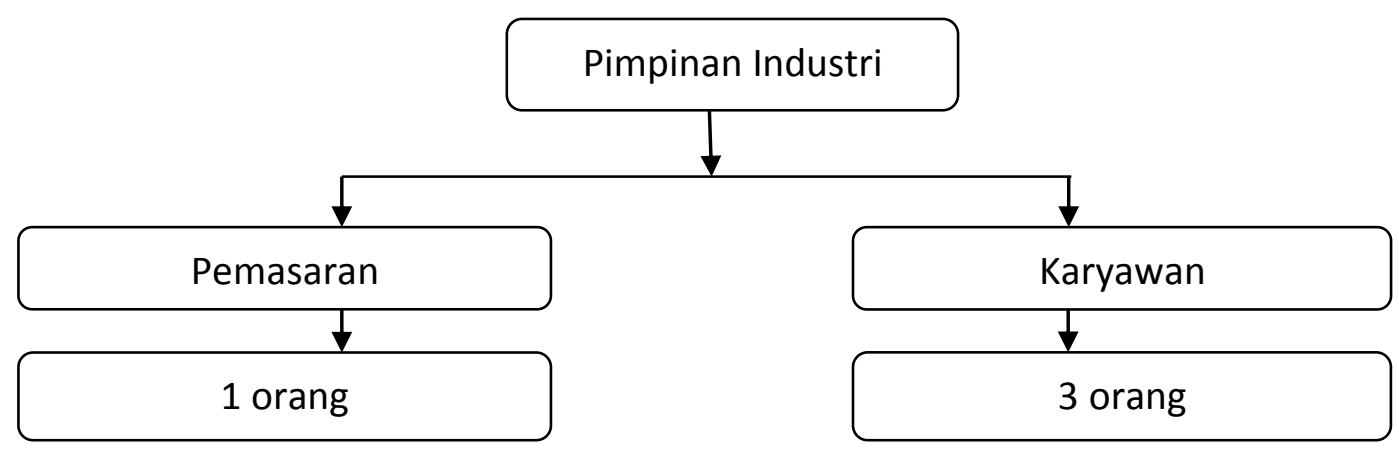

Gambar 1. Struktur Organisasi Industri Tahu di IKM Dwi Berkah

Struktur organisasi pada gambar menunjukkan bahwa industri tersebut menganut sistem organisasi lini (Line organizing) bentuk industri yang menggunakan struktur garis pada dasarnya masih sederhana, pemilik perusahaan biasanya bertindak sebagai pemimpin perusahaan, karyawannya relatif masih sedikit, dan masih saling mengenal serta hubungan antara pemimpin dan karyawan masih bersifat langsung. Adapun tugas dan tanggung jawab dari masing-masing karyawan yang telah ditetapkan oleh pimpinan industri adalah sebagai berikut:

a. Pimpinan

Pimpinan terdiri dari 1 (satu) orang yakni pemilik Industri Tahu di IKM Dwi Berkah yang sekaligus merangkap sebagai Bendahara dengan rincian tugas sebagai berikut: 


\section{P-ISSN: 2527-8479 E-ISSN: 2686-2174}

1) Bertanggung jawab atas aktivitas sehari-hari mengenai administrasi dan juga produksi.

2) Bertugas membuat perencanaan, pengorganisasian, melaksanakan dan mengontrol semua kegiatan produksi.

3) Bertugas merumuskan dan menetapkan kebijaksanaan industri dan memberi perinta kepada karyawanya.

4) Memberi motivasi kepada karyawan agar dapat bekerjasama dan meningkatkan keterampilan anggota karyawan dalam melaksanakan kegiatan produksi lebih efisien.

5) Memberi upah kepada karyawan setiap bulanya.

6) Melakukan transaksi pembayaran kepada pemasok bahan baku kedelai

7) Bertanggung jawab atas biaya operasional yang dikeluarkan setiap bulan, demi kelancaran produksi tahu.

\section{b. Bagian produksi}

Bagian ini tugas utamanya adalah bertanggung jawab terhadap jalanya produksi, 3 orang karyawan yang terlibat secara langsung dalam melakukan proses produksi. Bagian ini berperan mulai dari awal pembuatan sampai pada tahap produk siap di pasarkan.

c. Bagian pemasaran

Tugas utama bagian pemasaran yaitu mengatur kegiatan penjualan hasil produksi kepada konsumen, dengan melakukan penjualan di pasar maupun di Desa yang ada di Kecamatan Pasarwajo Kabupaten Buton untuk memenuhi permintaan konsumen.

\section{Tenaga Kerja}

Penggunaan tenaga kerja sejak Tahun 2003 yaitu menggunakan tenaga kerja yang ada disekitar Desa Kancinaa maupun keluarga dari sang pemilik usaha yang berjumlah 4 orang karyawan tetap. Uraian tenaga kerja yang dipergunakan dapat dilihat pada Tabel 3. sebagai berikut:

Tabel 3. Keadaan Tenaga Kerja Pembuatan Tahu Pada Industri Tahu di IKM Dwi Berkah Berdasarkan Umur, Jenis Kelamin, dan Pendidikan.

\begin{tabular}{|c|c|c|c|}
\hline No. Responden & Umur (Tahun) & Jenis Kelamin & Pendidikan \\
\hline 1 & 24 & Laki-laki & SMA \\
\hline 2 & 35 & Laki-laki & SMA \\
\hline 3 & 27 & Laki-laki & SMA \\
\hline 4 & 39 & Laki-laki & SMA \\
\hline
\end{tabular}

Informasi yang ada pada Tabel 3 menunjukkan bahwa tenaga kerja Industri Tahu di IKM Dwi Berkah umumnya berada pada klasifikasi umur produktif sedangkan menyangkut pendidikan hampir semuanya berstatus berpendidikan sehingga mampu menyesuaikan dengan pekerjaan yang diberikan oleh pemilik industri selaku pimpinan Usaha Industri Tahu di IKM Dwi Berkah di Desa Kancinaa Kecamatan Pasarwajo Kabupaten Buton.

Menurut soeharjo (2000) mengelompokkan umur berdasarkan kelompok produktif dan non produktif. Kisaran umur 15-55 tahun termaksud usia produktif sedangkan umur 0-14 tahun dan 55 tahun keatas dikategorikan umur non produktif. Berdasarkan tabel diatas dapat disimpulkan bahwa mengenai usia tenaga kerja pembuat tahu IKM Dwi Berkah adalah usia produktif. 


\section{P-ISSN: 2527-8479 E-ISSN: 2686-2174}

\section{Analisis Produksi Industri Tahu IKM Dwi Berkah}

Analisis produksi dalam penelitian ini terdiri dari beberapa sub bagian yang teliti yaitu: proses produksi, biaya usaha, penerimaan, keuntungan, dan $R / C$ Rasio.

\section{a. Proses Produksi}

Proses produksi merupakan teknik untuk menghasilkan atau menambah kegunaan suatu barang atau jasa dengan sumber-sumber yang tersedia seperti material, tenaga kerja, modal dan teknologi. Proses pembuatan tahu memerlukan beberapa alat dan bahan seperti. Alat yang digunakan dalam pembuatan tahu meliputi mesin penggiling, ember hitam, baskom besar, baskom kecil, pisau, kain penyaring, cetakan tahu, timbah, sepatu air, ember drum, drum plastic, arko keranjang, dan terpal. Bahan yang digunakan dalam pembuatan tahu yaitu, kayu bakar, cuka cair, bensin, kedelai. Adapun proses pembuatan tahu dapat dilihat pada gambar 2 sebagai berikut:

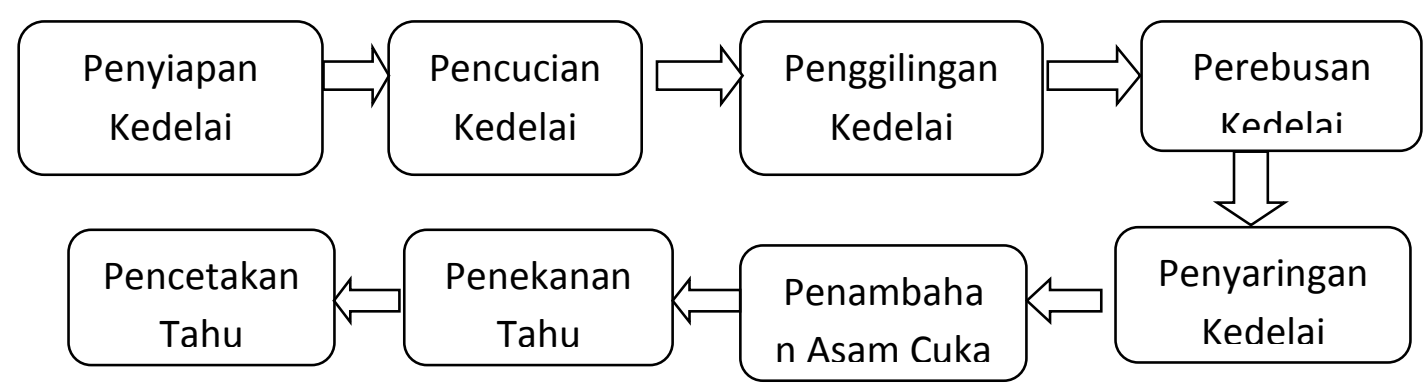

Gambar 2 : Proses Pembuatan Tahu

Dari Gambar 2 diatas menunjukkan bahwa proses pembuatan tahu pada Industri Tahu IKM Dwi Berkah yaitu:

1. 300kg kedelai yang akan digunakan dibersikan dengan cara di rendam menggunakan air yang bersih selama 8 jam. Dalam proses perendaman ini kedelai akan mengembang. Bersihkan kembali kedelai dengan cara di cuci berkali-kali.

2. Kedelai yang telah di rendam selama 8 jam kemudian dibersikan dengan cara di cuci berulang-ulang 3-4 kali sampai benar-benar bersih.

3. Setelah selesai kedelai dibersikan, kemudian kedelai dihancurkan menggunakan mesin penggiling hingga berbentuk bubur.

4. Setelah kedelai selesai dihancurkan hingga berbentuk bubur, kemudian kedelai di masak. Dalam proses perebusan bubur kedelai tidak boleh terlalu kental. Kemudian dalam proses perebusan bubur kedelai di tandai dengan adanya gelembung-gelembung kecil.

5. Kemudian kedelai yang telah masak diangkat dari wajan dan disaring menggunakan kain penyaring dengan menggunakan asam cuka sambil terus di aduk secara perlahan, hingga bubur kedelai menggumpal.

6. Dari gumpalan tahu yang telah ditambahkan asam cuka siap dipress yang berfungsi untuk menekan ampas agar kandungan airnya benar-benar habis.

7. Setelah gumpalan tahu di press, tahu kemudian di cetak segi empat, dan di pasarkan.

Langka-langka pembuatan tahu di Industri Tahu IKM Dwi Berkah, masih sangat sederhana dengan penggunaan alat-alat masih tradisional. Dalam proses pembuatan tahu masih di kerjakan oleh manusia, hanya sedikit menggunakan teknologi seperti penggunaan mesin penggiling. 


\section{b. Biaya Produksi}

Biaya (cost) adalah hasil dari semua input ekonomi yang diperlukan dan dapat diperkirakan untuk menghasilkan suatu produk atau nilai yang dinyatakan dengan uang dalam satuan rupiah $(\mathrm{Rp})$. Biaya yang diperlukan merupakan suatu pengorbanan yang perlu dan dapat diperkirakan, di mana biaya yang digunakan dapat dipastikan pada saat pelaksanaannya, dan dapat di ukur serta harus dapat di hitung jumlahnya dan dinyatakan dalam bentuk uang pada waktu penghitungan. Mulyadi (2007), mengemukakan bahwa biaya merupakan pengorbanan yang di ukur dengan satuan uang yang dilakukan untuk mencapai tujuan tertentu.

Ada dua jenis biaya pada Industri tahu IKM Dwi Berkah yaitu biaya variabel (variable cost) dan biaya tetap (fixed cost).

\section{Biaya Variabel (Variabel Cost)}

Biaya variabel (variable cost) yang dimaksud dalam penelitian ini adalah biaya yang habis terpakai dalam satu kali siklus produksi pada Industri Tahu IKM Dwi Berkah. Biaya variabel adalah biaya yang jumlah totalnya berubah sebanding dengan perubahan volume kegiatan. Biaya variabel per unit konstan tetapi semakin besar volume kegiatan semakin besar pula biaya totalnya, sebaliknya semakin kecil biaya volume kegiatan, semakin kecil pula biaya totalnya. Biaya variabel $(V C)$ yang di maksud dalam penelitian ini adalah biaya yang habis terpakai dalam satu kali proses produksi. Selanjutnya penggunaan biaya variabel pada Industri Tahu IKM Dwi Berkah, dapat dilihat pada tabel 4.

Tabel 4. Biaya Variabel yang digunakan Industri Tahu IKM Dwi Berkah di Desa Kancinaa Kecamatan Pasarwajo kabupaten Buton.

\begin{tabular}{|c|c|c|c|c|c|c|}
\hline No & Komponen Biaya & Jumlah & Satuan & $\begin{array}{c}\text { Harga } \\
\text { (Rp/satuan) }\end{array}$ & Biaya (RP/Bulan) & $\begin{array}{c}\text { Persentase } \\
\%\end{array}$ \\
\hline 1. & Kedelai Impor & 10.000 & $\mathrm{Kg}$ & 8.000 & 80.000 .000 & 80,53 \\
\hline 2. & Kedelai Lokal & 1.000 & $\mathrm{Kg}$ & 8.000 & 8.000 .000 & 8,05 \\
\hline 3. & Cuka Cair & 6 & $\mathrm{Bh}$ & 7.000 & 42.000 & 0,04 \\
\hline 4. & Kayu Bakar & 10 & Ret & 350.000 & 3.500 .000 & 3,53 \\
\hline 5. & Bensin & 150 & Liter & 10.000 & 1.500 .000 & 1,50 \\
\hline 6. & Upah Tenaga Kerja & 4 & Orang & 1.500 .000 & 6.000 .000 & 6,05 \\
\hline 7. & Sewa Listrik & 1 & Bulan & 200.000 & 200.000 & 0,20 \\
\hline \multirow[t]{2}{*}{8.} & Biaya Telpon/SMS & 1 & Bulan & 100.000 & 100.000 & 0.10 \\
\hline & Jumlah & & & & 99.342 .000 & 100 \\
\hline
\end{tabular}

Sumber: Data primer diolah Agustus, 2019

Proses produksi untuk menghasilkan output tidak terlepas dari biaya. Biaya usaha Industri Tahu merupakan biaya yang dikeluarkan oleh Industri dalam melakukan kegiatan usahanya atau biaya yang dikeluarkan Industri selama melakukan proses produksi. Sehingga besar kecilnya biaya yang dikeluarkan Industri Tahu IKM Dwi Berkah mempengaruhi produksi tahu seperti biaya Kedelai impor, upah tenaga kerja, kedelai lokal, kayu bakar, bensin, cuka cair, biaya telpon/sms, dan sewa listrik.

Berdasarkan Tabel 4 menunjukkan bahwa biaya yang tertinggi dari pembuatan tahu yang dilakukan Industri Tahu IKM Dwi Berkah selama Satu Bulan sebesar Rp. $80.000 .000 /$ bulan atau 80,53\% jika dipersentasekan untuk pembelian bahan baku kedelai 
impor. Kemudian diikuti biaya upah tenaga kerja sebesar Rp. 6.000 .000 atau $6.05 \%$ untuk membayar 4 orang karyawan.

Kedelai Impor diposisi berikutnya dengan besaran biaya Rp.8.000.000 atau 8,05\% .kemudian biaya kayu bakar sebear Rp.3.500.000 atau 3,53\%, diikuti bensin Rp.1.500.000 atau $1,50 \%$ Sedangkan biaya terendah adalah pada biaya Sewa Listrik, biaya telepon/sms dan pembelian Cuka cair yang berkisar sekitar Rp. 200.000, Rp. 100.000 dan Rp 42.000. Kemudian dapat disimpulkan Biaya Variabel yang dikeluarkan oleh Industri Tahu IKM Dwi Berkah di Desa Kancinaa Kecamatan Pasarwajo Kabupaten Buton Rp. 99.342.000/bulan

Berdasarkan jumlah biaya variabel yang digunakan Industri Tahu IKM Dwi Berkah dengan jumlah keseluruhan Rp 99.342.000 /bulan, untuk lebih jelasnya dapat dilihat pada lampiran 3.

\section{Biaya Tetap (Fixed Cost)}

Biaya tetap $(F C)$ yang di maksud dalam penelitian ini adalah biaya yang tidak habis dalam satu kali proses produksi dan untuk menunjang keberlangsungan industri pembuatan tahu, biaya tetap dalam pembuatan usaha tahu pada Industri Tahu IKM Dwi Berkah adalah dapat dilihat pada tabel 5:

Tabel 5. Biaya Tetap yang Digunakan Industri Tahu di IKM Dwi Berkah Desa Kancinaa Kecamatan Pasarwajo Kabupaten Buton.

\begin{tabular}{ccrrrr}
\hline No. & Komponen Biaya & Jumlah & $\begin{array}{c}\text { Harga } \\
\text { Rp/Unit })\end{array}$ & Total Harga & $\begin{array}{c}\text { Persentase } \\
(\%)\end{array}$ \\
\hline 1. & Mesin Penggiling & 2 & 2.500 .000 & 5.000 .000 & 29,05 \\
\hline 2. & Ember Tempat Tahu & 30 & 30.000 & 900.000 & 5,23 \\
\hline 3. & Tungku & 2 & 2.500 .000 & 5.000 .000 & 29,05 \\
\hline 4. & Baskom Besar & 2 & 40.000 & 80.000 & 0,46 \\
\hline 5. & Baskom Kecil & 24 & 10.000 & 240.000 & 1,39 \\
\hline 6. & Pisau & 2 & 10.000 & 20.000 & 0,12 \\
\hline 7. & Kain Penyaring & 1 & 35.000 & 35.000 & 0,20 \\
\hline 8. & Cetakan Tahu & 6 & 500.000 & 3.000 .000 & 17,4 \\
\hline 9. & Timba & 2 & 15.000 & 30.000 & 0,17 \\
\hline 10 & Sepatu Air & 5 & 100.000 & 500.000 & 2,91 \\
\hline 11. & Ember Drum & 4 & 250.000 & 1.000 .000 & 5,81 \\
\hline 12. & Drum Plastik & 2 & 15.000 & 30.000 & 0,17 \\
\hline 13. & Arko (Gerobak) & 1 & 400.000 & 400.000 & 2,32 \\
\hline 14. & Bola Lampu & 2 & 28.000 & 56.000 & 0,33 \\
\hline 15. & Terpal & 1 & 200.000 & 200.000 & 1,16 \\
\hline 16. & Keranjang & 24 & 30.000 & 720.000 & 4,18 \\
\hline & & & Jumlah & 17.211 .000 & 100 \\
\hline
\end{tabular}

Biaya tetap yang digunakan Industri Tahu IKM Dwi Berkah di Desa Kancinaa Kecamatan Pasarwajo Kabupaten Buton terdapat 16 (enam belas) komponen biaya yang digunakan dalam Satu Bulan, satu tahun bahkan 2 tahun dalam proses produksi tahu dari yang tertinggi sampai yang terendah biaya yang digunakan berupa biaya mesin penggiling, ember tempat tahu, tungku, baskom besar, baskom kecil, pisau, kain penyaring, cetakan tahu, timba, sepatu air, ember drum, drum plastik, arko, bola lampu, terpal, dan keranjang. Walaupun tidak 
habis dalam satu kali proses produksi, biaya tetap juga akan mengalami penyusutan kerja dari alat-alat produksi yang digunakan dalam memproduksi tahu.

Berdasarkan Tabel 5 diatas menunjukkan bahwa biaya mesin penggiling dan tungku adalah biaya tetap terbesar yaitu sebesar Rp. 5.000.000 atau 29,05\% sedangkan biaya terkecil adalah untuk biaya timba dan drum plastik Rp. 30.000 atau jika dipersentasekan 0,17\%. Jadi Biaya Tetap yang digunakan Industri Tahu di IKM Dwi Berkah Desa Kancinaa Kecamatan Pasarwajo Kabupaten Buton adalah Rp. 17.211.000.

Penyusutan dapat di hitung berdasarkan umur ekonomis dari alat-alat produksi. Untuk mengetahui nilai ekonomis dari masing-masing peralatan yang digunakan dalam pembuatan tahu pada Industri Tahu IKM Dwi Berkah, maka di hitung nilai penyusutan dalam satu kali produksi. Penyusutan dihitung menggunakan metode garis lurus yaitu nilai awal dari peralatan dikurangi dengan nilai sisa kem udian dibagi dengan umur ekonomis dari peralatan tersebut. Nilai awal diperoleh dari biaya yang digunakan untuk membeli peralatan tersebut sedangkan umur ekonomis di lihat dari lamanya penggunaan peralatan tersebut masih menguntungkan. Untuk lebih jelasnya mengenai penyusutan biaya tetap dalam penelitian ini dapat di lihat pada Tabel 6.

Tabel 6 : Biaya tetap yang mengalami penyusustan Industri Tahu IKM Dwi Berkah Desa Kancinaa Kecamatan Pasarwajo Kabupaten Buton.

\begin{tabular}{|c|c|c|c|c|c|c|c|c|}
\hline No. & $\begin{array}{c}\text { Komponen } \\
\text { Biaya }\end{array}$ & Jumlah & $\begin{array}{c}\text { Harga } \\
\text { (Rp/Unit) }\end{array}$ & Total nilai awal & $\begin{array}{l}\text { Total harga } \\
\text { akhir (Rp) }\end{array}$ & $\begin{array}{l}\text { Lama } \\
\text { pakai } \\
(\mathrm{Bln})\end{array}$ & $\begin{array}{c}\text { Penyusutan } \\
\text { (Rp/Bln) }\end{array}$ & $\begin{array}{c}\text { Persentase } \\
\%\end{array}$ \\
\hline 1. & $\begin{array}{c}\text { Mesin } \\
\text { Penggiling } \\
\end{array}$ & 2 & 2.500 .000 & 5.000 .000 & 4.500 .000 & 24 & 187.500 & 10,14 \\
\hline 2. & $\begin{array}{c}\text { Ember Tempat } \\
\text { Tahu }\end{array}$ & 30 & 30.000 & 900.000 & 810.000 & 1 & 810.000 & 43,84 \\
\hline 3. & Tungku & 2 & 2.500 .000 & 5.000 .000 & 4.500 .000 & 24 & 187.000 & 10,12 \\
\hline 4. & Baskom Besar & 2 & 40.000 & 80.000 & 72.000 & 3 & 24.000 & 1,29 \\
\hline 5. & Baskom Kecil & 24 & 10.000 & 240.000 & 216.000 & 6 & 36.000 & 1,95 \\
\hline 6. & Pisau & 2 & 10.000 & 20.000 & 18.000 & 12 & 1.500 & 0,08 \\
\hline 7. & $\begin{array}{c}\text { Kain } \\
\text { Penyaring } \\
\end{array}$ & 1 & 35.000 & 35.000 & 3.500 & 2 & 15.750 & 0,85 \\
\hline 8. & Cetakan Tahu & 6 & 500.000 & 3.000 .000 & 2.700 .000 & 12 & 225.000 & 12,18 \\
\hline 9. & Timba & 2 & 15.000 & 30.000 & 27.000 & 2 & 13.500 & 0,73 \\
\hline 10 & Sepatu Air & 5 & 100.000 & 500.000 & 450.000 & 3 & 150.000 & 8,12 \\
\hline 11. & Ember Drum & 4 & 250.000 & 1.000 .000 & 900.000 & 36 & 30.000 & 1,62 \\
\hline 12. & Drum Plastik & 2 & 15.000 & 30.000 & 25.000 & 1 & 25.000 & 1,35 \\
\hline 13. & $\begin{array}{c}\text { Arko } \\
\text { (Gerobak) }\end{array}$ & 1 & 400.000 & 400.000 & 360.000 & 24 & 15.000 & 0,81 \\
\hline 14. & Bola Lampu & 2 & 28.000 & 56.000 & 50.400 & 12 & 4.200 & 0,22 \\
\hline 15. & Terpal & 1 & 200.000 & 200.000 & 180.000 & 12 & 15.000 & 0,81 \\
\hline \multirow[t]{2}{*}{16.} & Keranjang & 24 & 30.000 & 720.000 & 648.000 & 6 & 108.000 & 5,84 \\
\hline & Jumlah & & & & & & 1.847 .450 & 100 \\
\hline
\end{tabular}

Sumber: Data primer diolah, Agustus 2019

Berdasarkan Tabel 6 menunjukkan bahwa jumlah biaya tetap pada Industri Tahu IKM Dwi Berkah pada Satu Bulan yang paling tertinggi adalah ember tempat tahu dengan penyusutan sebesar Rp 810.000/bulan dan biaya yang paling rendah adalah pisau dengan penyusutan sebesar Rp. 1.500/bulan. Sedangkan jumlah keseluruan biaya penyusutan Industri 


\section{P-ISSN: 2527-8479 E-ISSN: 2686-2174}

Tahu IKM Dwi Berkah adalah sebesar Rp 1.847.450/bulan untuk lebih jelasnya dapat dilihat pada lampiran 3.

Biaya tetap awal industry tahu IKM Dwi Berkah adalah Rp. 17.211.000 sedangkan biaya penyusutan barangnya adalah Rp. 1.847.450. untuk mengetahu biaya tetap bersihnya industry tahu ini adalah dengan mengurangkan biaya tetap awal tadi dengan biaya penyusutan. Untuk lebih jelasnya dapat kita lihat pada tabel 7 di bawah ini:

Tabel 7. Biaya tetap bersih industry tahu IKM Dwi Berkah

\begin{tabular}{rcr}
\hline No. & Uraian & Jumlah (Rp) \\
\hline 1. & Biaya tetap awal( investasi ) & 17.211 .000 \\
\hline 2. & Biaya penyusutan & 1.847 .450 \\
\hline 3 & Biaya Tetap (FC) & 15.363 .550 \\
\hline
\end{tabular}

Jadi biaya tetap (FC) industry tahu IKM Dwi Berkah adalah Rp. 15.363.550 ini adalah biaya tetap bersih yang sudah dikurangi dengan biaya penyusutan barang.

\section{Biaya Total (Total Cost)}

Biaya total (total cost) adalah jumlah dari biaya tetap dan biaya variabel. Biaya total yang digunakan Industri Tahu IKM Dwi Berkah dalam Satu Bulan di Desa Kancinaa Kecamatan Pasarwajo Kabupaten Buton dapat dilihat pada Tabel 8.

Tabel 8. Biaya Total yang Digunakan Industri Tahu IKM Dwi Berkah di Desa Kancinaa Kecamatan Pasarwajo Kabupaten Buton

\begin{tabular}{|c|c|c|c|}
\hline $\mathrm{No}$ & Biaya Total & Jumlah & Persentase \% \\
\hline 1. & Biaya Tetap & 15.363 .550 & 13.40 \\
\hline 2. & Biaya Variabel & 99.342 .000 & 86,60 \\
\hline & Total & 114.705 .550 & 100 \\
\hline
\end{tabular}

Berdasarkan Tabel diatas dapat dilihat bahwa nilai total biaya tetap yang dikeluarkan oleh Industri Tahu IKM Dwi Berkah dalam Satu Bulan, sebesar Rp 15.363.550/bulan dan nilai total biaya variabel dalam Satu Bulan sebesar Rp 99.342.000/bulan, dari kedua biaya tersebut yang tertinggi biaya variabel ini disebabkan karena jumlah pemesanan bahan baku kedelai impor yang lebih tinggi. Sehingga untuk mendapatkan total biaya dalam proses produksi tahu pada Industri Tahu IKM Dwi Berkah, biaya tetap ditambah dengan biaya variabel sehingga jumlah dari biaya total yang digunakan dalam Rp. 114.705.550/bulan.

\section{Penerimaan (Revenue)}

Kegiatan usaha yang dilakukan oleh seseorang akan menghasilkan suatu penerimaan yang diterima, dalam hal ini Industri Tahu IKM Dwi Berkah. Penerimaan yang dimaksud dalam penelitian ini adalah perkalian antara produksi yang diperoleh dengan harga jual yang telah disepakati bersama antara penjual dan pembeli

Tabel 9. Jumlah Produksi yang Digunakan Industri Tahu IKM Dwi Berkah di Desa Kancinaa Kecamatan Pasarwajo Kabupaten Buton. 


\begin{tabular}{|c|c|c|r|c|}
\hline \multicolumn{2}{|c|}{ Jumlah } & Satuan & Harga/satuan (Rp) & Penerimaan \\
\hline \multirow{2}{*}{ Hari } & 90 & Cetakan & 1.000 & 5.760 .000 \\
& 5.760 & Potong & & \\
\multirow{2}{*}{ Bulan } & 2.700 & Cetakan & 1.000 & 172.800 .000 \\
\hline
\end{tabular}

Sumber: Data primer diolah, Agustus 2019

Berdasarkan Tabel 9 menunjukkan bahwa Industri Tahu IKM Dwi Berkah dalam satu hari produksi tahu yaitu sebanyak 90 cetakan masing-masing cetakan menghasilkan 64 potong tahu (10 x $10 \mathrm{~cm} /$ potong), dengan pemakaiaan bahan baku kedelai sebanyak 11.000 kg kedelai impor dan kedelai lokal perbulannya. Sedangkan untuk perharinya pemakaian bahan baku sekitar $\pm 330 \mathrm{~kg}$ kedelai impor dan kedelai local $\pm 33.3 \mathrm{~kg}$ dengan jumlah produksi per hari Rp 5.760 potong dengan harga Rp 1.000/potong, sehingga penerimaan dalam satu Bulan proses produksi pada Industri Tahu IKM Dwi Berkah sebesar Rp. 172.800.000/bulan.

\section{Keuntungan}

Keuntungan merupakan selisih antara penerimaan dan semua biaya total produksi yang dikeluarkan Industri Tahu IKM Dwi Berkah. Keuntungan yang diterima Industri Tahu IKM Dwi Berkah dalam satu bulan sesuai jumlah laku tahu yang di beli oleh konsumen. Keuntungan yang diterima Industri Tahu IKM Dwi Berkah tentunya telah dikurangi dengan semua biaya yang digunakan pada saat proses produksi tahu yang dihasilkan.

Hal ini sesuai dengan pendapat yang dikemukakan oleh Kartasapoetra (1988), bahwa keuntungan bersih suatu usaha menunjukkan imbalan yang diperoleh dari pengeluaran faktorfaktor produksi yang berupa tenaga kerja, pengelolaan, manajemen dan modal sendiri.

Tabel 10. Keuntungan yang dihasilkan Industri Tahu IKM Dwi Berkah di Desa Kancinaa Kecamatan Pasarwajo Kabupaten Buton.

\begin{tabular}{ccr}
\hline No. & Uraian & Jumlah $(\mathrm{Rp})$ \\
\hline 1. & Penerimaan & 172.800 .000 \\
\hline 2. & Biaya Total & 114.705 .550 \\
\hline 3 & Keuntungan & 58.094 .450 \\
\hline
\end{tabular}

Sumber: Data primer diolah, Agustus 2019

Industri Tahu IKM Dwi Berkah dalam proses produksi serta pemasaran tahu menghasilkan penerimaan dalam satu bulan Rp 172.800.000/bulan dalam proses ini penerimaan yang diterima cukup tinggi. Sedangkan total biaya yang digunakan cukup efisien.

Berdasarkan Tabel 10 dapat diketahui bahwa penerimaan yang diperoleh Usaha Industri Tahu IKM Dwi Berkah dalam satu Bulan proses produksi yaitu sebesar Rp 172.800.000/bulan sedangkan biaya total yang digunakan dalam satu Bulan proses produksi sebesar Rp. 114.705.550 /bulan. Dari kedua biaya tersebut yang meliliki jumlah tertinggi total penerimaan dibanding dengan biaya total yang digunakan pada Industri Tahu IKM Dwi 


\section{P-ISSN: 2527-8479 E-ISSN: 2686-2174}

Berkah. Sehingga diketahui keuntungan yang diperoleh Industri Tahu IKM Dwi Berkah dalam Satu Bulan sebesar Rp 58.094.450/bulan.

\section{Analisis $R / C$ Rasio}

$R / C$ ratio merupakan salah satu analisis yang digunakan untuk mengetahui apakah usaha Industri Tahu IKM Dwi Berkah dalam Satu Bulan produksi di Desa Kancinaa Kecamatan Pasarwajo Kabupaten Buton mengalami kerugian, impas, dan untung. Dengan cara membandingkan antara jumlah penerimaan $(T R)$ dan jumlah total biaya (TC). Lebih jelasnya dapat dilihat pada Tabel 11.

Tabel 11. Nilai $R / C$ ratio Industri Tahu IKM Dwi Berkah di Desa Kancinaa Kecamatan Pasarwajo Kabupaten Buton.

\begin{tabular}{|c|c|c|c|}
\hline No. & $\begin{array}{c}\text { Total Penerimaan } \\
(T R)\end{array}$ & Total Biaya & Nilai $R / C$ Rasio \\
\hline 1. & 172.800 .000 & 114.705 .550 & 1,51 \\
\hline
\end{tabular}

Sumber: Data primer diolah, Agustus 2019

Berdasarkan Tabel 11 bahwa rata-rata penerimaan $T R$ sebesar Rp 172.800.000/bulan dan rata-rata total biaya $T C$ sebesar Rp 114.705.550/bulan yang memberikan nilai $R / C$ ratio sebesar 1,51. Dengan demikian Usaha Industri Tahu IKM Dwi Berkah di Desa Kancinaa Kecamatan Pasarwajo Kabupaten Buton produktif atau menguntungkan dan layak untuk dikembangkan.

Industri Tahu IKM Dwi Berkah dilihat dari nilai $R / C$ yang layak di kembangkan diperoleh dalam satu bulan dengan total penerimaan cukup besar, dan biaya total yang digunakan Industri Tahu IKM Dwi Berkah cukup efisien, untuk memproduksi tahu yang dihasilkan. Industri Tahu IKM Dwi Berkah dalam mempertahankan dan meningkatkan keuntungan dan efisiensi sebaiknya Industri Tahu IKM Dwi Berkah mempertahankan kualitas dan dapat meningkatkan kuantitasnya.

Kartasapoetra (1988), mengemukakan bahwa apabila nilai R/C >1 maka usaha tersebut menguntungkan dan penggunaan biaya efisien ini menunjukkan bahwa dengan pengeluaran biaya awal sebesar Rp 114.705.550 (Lampiran 3 tabel 7 pada Industri Tahu IKM Dwi Berkah menghasilkan nilai penerimaan atau revenue sebesar Rp. 172.800 .000 atau setiap pengeluaran 1 satuan akan memberikan penerimaan sebesar $R / C 1,51$ satuan (Lampiran 3 tabel 8). Dengan demikian Usaha Industri Tahu IKM Dwi Berkah di Desa Kancinaa Kecamatan Pasarwajo Kabupaten Buton produktif atau menguntungkan dan layak untuk dikembangkan serta penggunaan biaya produksi efisien.

\section{KESIMPULAN DAN SARAN}

\section{Kesimpulan}

Berdasarkan hasil penelitian, maka dapat ditarik kesimpulan sebagai berikut:

a. Pendapatan yang diperoleh dari Industri IKM Dwi Berkah di Desa Kancinaa Kecamatan Pasarwajo Kabupaten Buton sebesar Rp. 58.094.450/bulan.

b. Nilai analisis R/C rasio sebesar 1,51 artinya setiap pengeluaran sebesar Rp. 1.000 dan penerimaannya RP. 1.510. Hal ini menunjukkan bahwa usaha Industri Tahu IKM Dwi Berkah layak untuk dikembangkan. 


\section{P-ISSN: 2527-8479 E-ISSN: 2686-2174}

\section{Saran}

Berdasarkan hasil penelitian, penulis menyarankan hal-hal sebagai berikut.

a. Diharapkan kepada pengelola Industri Tahu IKM Dwi Berkah untuk tetap mempertahankan penghasilan keuntungan yang di peroleh dengan cara lebih memperhartikan persedian bahan baku agar mendapatkan hasil yang lebih optimal.

b. Diharapkan kepada pengelola Industri Tahu IKM Dwi Berkah untuk meningkatkan pengelolaan tempat dengans membuat sebuah pembukuan atau pencatatan financial yang baik agar terkontrol biaya pemasukan maupun pengeluaran yang dilakukan dalam memproduksi tahu sehingga pemilik tahu dapat melihat peningkatan atau penurunan yang terjadi pada kondisi keuangan.

c. Peralatan yang digunakan hendaknya selalu dirawat agar kehigienisan tahu terjaga dengan baik.

d. Kepada pemerintah diharapkan agar lebih memperhatikan industri kecil khususnya industri pengolahan tahu.

\section{DAFTAR PUSTAKA}

Assauri, S. 2004. Manajemen Pemasaran. Raja Grafindo Persada, Jakarta.

Badan Pusat Statistik. 2017. Rata-rata Konsumsi per Kapita Seminggu Beberapa Macam Bahan Makanan penting 2017. BPS. Jakarta.

Cahyadi, W., (2007), Kedelai Khasiat dan Teknologi, Bumi Aksara, Jakarta.

J. Setiadi, Nugroho. (2008), Perilaku Konsumen, Jakarta: PT Kencana.

Kuncoro. 2007. Industri Ekonomi. Andi, Yogyakarta.

Kartasapoetra. 1988. Kalkulasi dan Pengendalian Biaya. Produksi. Jakarta: Bina Aksara.

Sarwono, B. 2005. Membuat Aneka Tahu. Penebar Swadaya. Jakarta

Suratiyah,K. 2015. Ilmu Usahatani.Jakarta: Penebar Swadaya.

Warisno dan Kres Dahana. 2010. Meraup Untung dari Olahan Kedelai. : PT AgroMedia Pustaka. 